\title{
Sistem Pendukung Keputusan Kelompok Penentuan Kelayakan Lokasi Pemukiman
}

\author{
Mutammimul Ula ${ }^{* 1}$, Azhari $\mathrm{SN}^{2}$ \\ ${ }^{1}$ Program Studi S2/S3 Ilmu Komputer, FMIPA UGM \\ ${ }^{2}$ Jurusan Ilmu Komputer dan Elektronika, FMIPA UGM \\ e-mail: "1mutammimul_gam@yahoo.com, 2 arisn,soft.comp@gmail.com
}

\begin{abstract}
Abstrak
Sebagai daerah yang rawan bencana dari tsunami, dan abrasi gelombang laut, dibutuhkan suatu lokasi yang layak untuk dapat dijadikan suatu daerah pemukiman untuk mendukung perkembangan perekonomian, sarana dan prasarana, serta sosial ekonomi di pemerintah kota Lhokseumawe. Oleh sebab itu, diperlukan penentuan kelayakan lokasi pemukiman yang layak untuk direkomendasi menjadi sebuah pemukiman yang akan dibangun. Sehingga perlu dilakukan evaluasi terhadap areal fisik pemukiman, sarana dan prasarana, dan sosial-ekonomi yang akan direkomendasi menjadi suatu lokasi pemukiman. Masukan dari masyarakat sangat dibutuhkan untuk mengetahui masalah lokasi yang akan direkomendasi menjadi sebuah pemukiman. Hal ini dilakukan agar pihak pengawas mengetahui dan dapat mengantisipasi masalah-masalah yang terjadi pada lokasi tersebut. Penerapan sistem pendukung keputusan kelompok atau Group Decision Support System (GDSS) yang dibuat menggunakan metode VIKOR (Vlse Kriterijumska Optimizacija Kompromisno Resenje in Serbia) dapat membantu para pengambil keputusan dalam melakukan perankingan nilai masing-masing alternatife solusi, entropy sebagai pembobotannya dari setiap kriteria.. Sementara metode Copeland score, sebagai salah satu metode voting yang tekniknya berdasarkan pengurangan frekwensi kemenangan dengan frekwensi kekalahan dari perbandingan berpasangan untuk melakukan voting terhadap solusi yang akan di ambil para decision maker.
\end{abstract}

Kata kunci- GDSS, Vikor, Entropy, Copeland Score, lokasi pemukiman.

\begin{abstract}
Abstrak
As a disaster-prone areas of the tsunami, ocean waves and abrasion, it takes a decent location to be used as a residential area to support economic development, infrastructure, social and economic development of Regional Goverment of Lhokseumawe. Therefore, it is necessary to have feasibility determination of viable residential locations as recommendation to be a settlement. So it is necessary to evaluate the physical area of settlements, infrastructure, economic and social development that will be recommended to be a residential location. Public suggestion is needed to determine the problem locations to be recommended to a settlement. The application of group decision support systems or Group Decision Support System (GDSS) are made using the VIKOR method (Vlse Kriterijumska Optimizacija Kompromisno Resenje in Serbia) that is able to assist decision makers in the ranking value to each solution alternatives, entropy wih weigt for criterias, the method of Copeland score, as one method of voting is the technique by reducing the frequency of victory with the defeat of the comparison frequency pairs can be used to vote for a solution that will take the decision makers.
\end{abstract}

Keyword - GDSS, Vikor, Copeland Score, Entropy, location determination. 


\section{PENDAHULUAN}

$\mathrm{L}$ hokseumawe merupakan wilayah pesisir yang rentan terhadap gangguan seperti bahaya tsunami, abrasi, dan daerah pemukiman yang kumuh. Pemberian rekomendasi untuk lokasi pemukiman baru sangat dibutuhkan untuk meminimalkan resiko jangka panjang terhadap kelangsungan hidup masyarakat. Pemukiman merupakan tempat berlangsungnya berbagai macam usaha/kegiatan masyarakat baik ekonomi maupun sosial. Oleh karena itu jangkauan masyarakat terhadap sarana dan prasana sangat mendukung kesejahteraan suatu pemukiman, misalnya adanya mitigasi tsunami, kebutuhan akan kesehatan, transportasi dan pelayanan pemerintahan.

Selama ini, penentuan kelayakan lokasi pemukiman dilakukan secara manual, sehingga membutuhkan waktu dalam melakukan proses penyeleksian. Permasalahan selanjutnya adalah bagaimana pengambil keputusan melakukan penilaian terhadap lokasi yang tepat, apakah lokasi sudah memenuhi kriteria yang ditetapkan sebagai sebuah pemukiman. Kemudian kesalahan penentuan lokasi pemukiman yang terjadi di wilayah pesisir pantai Lhokseumawe akan mengakibatkan sulitnya masyarakat untuk melangsungkan kehidupan yang lebih baik. Berdasarkan permasalahan tersebut, penentuan lokasi pemukiman bagi masyarakat pesisir pantai wilayah Lhokseumawe sangat dibutuhkan. Informasi yang tepat dan cepat mengenai lokasi-lokasi yang layak dapat direkomendasikan menjadi wilayah pemukiman baru, sehingga terciptanya kesejhteraan mayarakat pesisir.

Peran para pengambil keputusan menjadi sangat penting dalam penentuan lokasi pemukiman yang lebih layak. Tetapi hal tersebut menjadi tidak mudah jika masing-masing pihak pengambil keputusan memiliki alternatif ataupun kriteria-kriteria berbeda sehingga menghasilkan keputusan yang berbeda. Kemudian sulitnya para pengambil keputusan dari dinas masing-masing yang memiliki alternatif lokasi atau kriteria yang berbeda dalam pengambilan keputusan sehingga dari keputusan yang berbeda tersebut akan menjadi sebuah suatu keputusan yang akan direkomendasikan untuk sebuah lokasi pemukiman.

Dalam kasus ini yang menjadi objek penelitian adalah Penentuan Kelayakan Pemukiman Pesisir Pantai Kota Lhokseumawe. Pengambil keputusan menggunakan metode entropy digunakan untuk menghitung bobot pada setiap kriteria dalam menentukan kelayakan pemukiman. Kemudian nilai pembobotannya dimasukkan dalam perhitungan vikor. Hasil dari masing-masing vikor dimasukkan kedalam Group menggunakan metode Copeland score. Beberapa keuntungan dari sebuah sistem pendukung keputusan kelompok atau Group Decision Support System (GDSS), diantaranya dapat mendukung aktivitas kelompok, memberikan kecepatan hasil akhir keputusan yang akan diperoleh, setiap pengambil keputusan dapat mengkalkulasikan keputusan secara online dari manapun, dan dapat dilakukan secara bersamasama pada saat yang bersamaan atau tidak bersamaan[1]. Penggunaan sistem pendukung keputusan berbasis kelompok pada penelitian ini adalah untuk meningkatkan kualitas keputusan, sehingga penilaian yang dilakukan lebih objektif, karena pengambilan keputusan tidak dilakukan oleh satu pihak.

Penelitian [1], sistem dibuat untuk aplikasi industri desainer produk sebagai pilihan material yang didasarkan pada properti mekanik dan kimia. Hasil yang akan dicapai solusi ideal dalam melakukan pemilihan bahan dengan memperhitungkan nilai resiko kegagalan[2].

Penelitian [2], sistem pendukung keputusan yang dibuat untuk modifikasi pada klasifikasi pembagian tanah Berdasarkan Kerentanan Daerah Aliran Sungai (DAS). Berbagai saluran dari tanah di sekitar DAS memiliki berbagai tingkat kerentanan lingkungan. Hasil yang diperoleh menunjukkan bahwa penggunaan lahan yang padat negara Taiwan dibatasi sesuai dengan tingkat kepentingan untuk daerah yang padat lokasi [3].

Penelitian [4], sistem dibuat untuk pemilihan strategi pemasaran.Hasilpenelitian perhitungan setiap kriteria dan alternatif dapat ditentukan menggunakan metode linear goal programming dan pengambilan keputusan pada masing-masing bobot menggunakan fuzzy vikor dengan melihat prioritas mana yang lebih penting untuk strategi yang tepat dalam pemasaran menggunakan model goal linear programming dan fuzzy VIKOR[4]

IJCCS Vol. 7, No. 1, January 2013: $89-100$ 


\section{METODE PENELITIAN}

\subsection{Analisa}

Permasalahan telah dipaparkan pada latar belakang yang mendasari untuk dilakukan penelitian ini adalah: (1) Informasi yang tepat mengenai lokasi-lokasi yang akan direkomendasikan menjadi wilayah pemukiman akan terlalu sulit, karena setiap dinas memiliki kriteria yang berbeda-beda; (2) Sulitnya para pengambil keputusan dari dinas masing-masing memiliki alternatif lokasi atau kriteria yang berbeda dalam pengambilan keputusan sehingga dari keputusan yang berbeda tersebut akan menjadi sebuah suatu keputusan yang akan direkomendasikan untuk sebuah lokasi pemukiman; (3) Kesalahan pemberian rekomendasi dalam penentuan lokasi pemukiman di wilayah pesisir pantai Lhokseumawe akan mengakibatkan lokasi tersebut tidak ditempati oleh masyarakat pesisir; (4) Banyaknya kriteria yang dipertimbangkan dalam pengambilan keputusan diperlukan suatu perhitungan secara cepat dan mudah. Oleh karena itu diperlukan Sistem pendukung keputusan kelompok (GDSS) penentuan kelayakan lokasi pemukiman digunakan untuk membantu decision maker dalam memberikan rekomendasi pemukiman yang tepat di pemerintah kota Lhokseumawe. Model vikor digunakan untuk proses seleksi kelayakan lokasi pemukiman pada sistem dilakukan dengan menggunakan metode. Entropy digunakan untuk pembobotan pengambilan keputusan tidak dapat diukur secara tepat, penilaian berdasarkan subjektifitas atau pengalaman pribadinya sendiri. Copeland score digunakan untuk solusi dari masing-masing pengambil keputusan. Data yang dibutuhkan oleh sistem berupa data internal dan ekternal.

\subsection{Perancangan Sistem}

Sistem pendukung keputusan kelompok penentuan kelayakan lokasi menggunakan model vikor, entropy dan metode copeland score. Arsitektur GDSS ini terdapat 3 decision maker yang terlibat yaitu pimpinan dinas bappeda, dinas pu yang terdiri dari kepala subbidang tata ruang dan kepala sub bidang perkim. Hubungan antara para decision maker, dihubungkan oleh suatu koneksi jaringan internet, dimana semua data nya disimpan pada database server pusat database lokasi.

Arsitektur GDSS sistem pendukung keputusan kelompok penentuan kelayakan pemukiman dapat lihat pada Gambar 1.

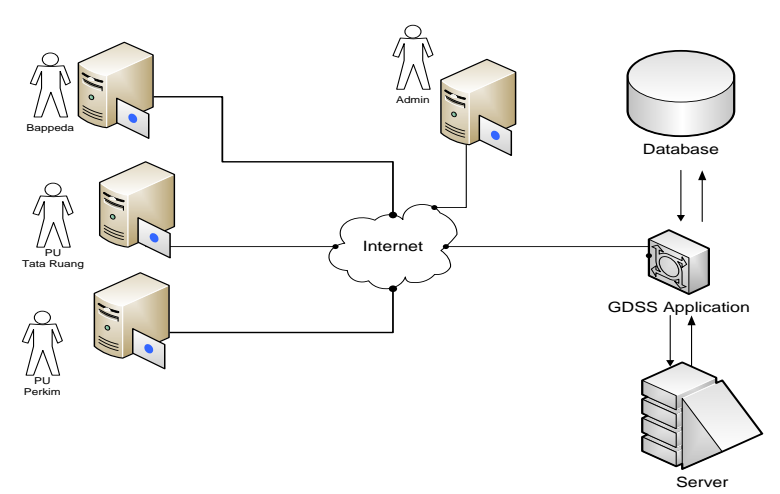

Gambar 1 Arsitektur GDSS penentuan dana kelayakan lokasi pemukiman

Pemodelan data Kriteria Pengolahan data mentah menjadi model adalah untuk menentukan subkriteria pengambilan keputusan yang akan dijadikan pemilihan lokasi berdasarkan penilaian yang telah dibuat rule oleh decision maker masing-masing. Pengambilan kriteria yang akan dijadikan model berdasarkan referensi dan data dari instansi dinas masingmasing. Data yang telah dijadikan sebuah model untuk kemudian dipilih oleh decision maker. 
Adapun penilaian dari subkriteria masing-masing decision maker adalah:

1. Pemodelan kelayakan pemukiman badan berencanaan pembangunan daerah untuk data pemodelan kriteria berupa: (a) kriteria kondisi lahan dengan subkriteria kemiringanlereng (derajat), tekstur tanah dan batuan, kedalaman muka air tanah,; (b)kriteria bahaya tsunami dan gempa bumi mempunyai subkriteria Kelerengan Pantai, Elevasi jarak Landaan (Run Up)meter, (c) Intensitas Gempa Bumi (MMI); (c) Longsor dan banjir yang mempunyai subkriteria Tingkat Bahaya Longsor, dan banjir dan geangan.

2. Kriteria dan Penilaian Tata Ruang yang memberikan penilaian sarana dan prasarana berupa : (a) ktriteria fasilitas transportasi yang mempunyai subkrtiteria sarana transportasi dan fasilitas terminal; (b)Kriteria fasilitas pendukung yang mempunyai subkriteria Pelayanan Air Bersih;(b)Kebutuhan Listrik; (c) tingkat keamana. Kriteria kelebagaan yang mempunyai subkriteria departemen pemerintah, departemen non pemerintah.

3. Kriteria dan penilaian perkim pada bidang perumahan dan pemukiman(perkim) yang mempunyai kriteria kondisi kesuaian jarak yang mempunyai subkriteria pemerintah, perdagangan, kesehatan, dan bank. Selanjutnya kriteria sosial ekonomi dengan subkriteria jumlah penduduk, dan peluang pekrjaan.

Perhitungan nilai vikor dengan data masukan.

1. Memasukkan nilai vikor

Tabel 1 nilai kecocokan vikor

\begin{tabular}{|l|l|l|l|l|l|}
\hline \multirow{2}{*}{$\begin{array}{l}\text { Kriteria } \\
\text { Jarak (meter) }\end{array}$} & \multicolumn{5}{|c|}{ Lokasi } \\
\cline { 2 - 6 } & Alue lim & Blang buloh & $\begin{array}{l}\text { Mane } \\
\text { kareung }\end{array}$ & Asan kareung & Rayeuk kareng \\
\hline Pendidikan & 3.80 & 3.00 & 3.00 & 2.50 & 4.99 \\
\hline Bank & 3.50 & 4.00 & 3.00 & 4.00 & 4.50 \\
\hline Pusat kesehatan & 4.60 & 4.25 & 3.70 & 2.75 & 2.00 \\
\hline pemerintahan & 4.30 & 2.50 & 1.95 & 2.00 & 2.40 \\
\hline Perdagangan & 3.80 & 4.25 & 2.50 & 2.25 & 2.85 \\
\hline Jumlah penduduk & 4.00 & 3.75 & 3.65 & 0.67 & 4.00 \\
\hline Peluang pekerjaan & 3 & 1 & 3 & 3 & 5 \\
\hline
\end{tabular}

2. Normalisasi

Menghitung nilai normalisasi dengan mengalikan nilai pada tiap alternatif di matriks normaliasi. Persamaan yang digunakan adalah:

$$
f_{i j}=\frac{x_{i j}}{\sqrt{\sum_{i=1}^{m} x^{2}}}
$$

Keterangan simbol :

$\mathrm{x}_{\mathrm{i}}=$ nilai normalisasi dari tiap alternatif $(\mathrm{i})$ terhadap kriteria $(\mathrm{j})$ dengan $\mathrm{i}=1,2, \ldots, \mathrm{m}$; dan $\mathrm{j}=$ $1,2, \ldots, \mathrm{n}$.

$\mathrm{x}_{\mathrm{j}}=$ kriteria ke-j $1,2, \ldots, \mathrm{n}$, dan $\mathrm{x}_{\mathrm{ij}}$ merupakan performa alternatf $\mathrm{A}_{\mathrm{i}}$ ke kriteria $\mathrm{j}$.

Tabel 2 Normalisasi

\begin{tabular}{|l|l|l|l|l|l|}
\hline \multirow{2}{*}{$\begin{array}{c}\text { Kriteria } \\
\text { Jarak (meter) }\end{array}$} & \multicolumn{5}{c|}{ Lokasi } \\
\cline { 2 - 6 } & Alue lim & Blang buloh & Mane kareung & Asan kareung & Rayeuk kareng \\
\hline Pendidikan & 0.369472 & 0.33041 & 0.374810 & 0.359633 & 0.48923 \\
\hline Bank & 0.340303 & 0.440552 & 0.374810 & 0.575412 & 0.4411 \\
\hline Pusat kesehata & 0.447256 & 0.468087 & 0.462265 & 0.395596 & 0.19608 \\
\hline pemerintahan & 0.418087 & 0.275345 & 0.243626 & 0.287706 & 0.23530 \\
\hline Perdagangan & 0.369472 & 0.468087 & 0.312341 & 0.323669 & 0.27942 \\
\hline Jumlah penduduk & 0.388918 & 0.413018 & 0.456018 & 0.096382 & 0.39217 \\
\hline Peluang pekerjaan & 0.291689 & 0.110138 & 0.374810 & 0.431559 & 0.49021 \\
\hline
\end{tabular}

IJCCS Vol. 7, No. 1, January 2013 : 89-100 
3. Menghitung nila solusi psoistif ideal dan negatif

Solusi ideal positif $\left(f^{*}\right)$ diperoleh dengan mencari nilai maksimal dari nilai normalisasi $\left(f_{i j}\right)=$ Solusi ideal negatif $\left(f^{-}\right)$diperoleh dengan mencari nilai minimal dari nilai normalisasi $\left(f_{i j}\right)$.

4. Perhitungan nilai bobot entropy

Pemberian bobot awal. maka hasil bobot entropy yang sebenamya untuk tiap kriteria akan didapat dengan persamaan berikut ini :

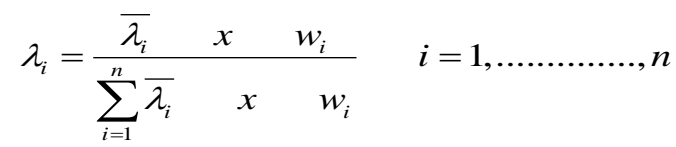

$\lambda_{\mathrm{i}} \quad=$ bobot entropy sebenarnya untuk kriteria ke-i

$\mathrm{W}_{\mathrm{i}}=$ bobot awal kriteria ke- $\mathrm{i}$

Tabel 3 Bobot entropy

\begin{tabular}{|l|l|l|}
\hline \multirow{2}{*}{$\begin{array}{c}\text { Kriteria } \\
\text { Jarak (meter) }\end{array}$} & Lokasi \\
\cline { 2 - 3 } & Bobot awal & Lamda [i] GAP \\
\hline Pendidikan & 0.12 & 0.115684 \\
\hline Bank & 0.13 & 0.120626 \\
\hline Pusat kesehatan & 0.12 & 0.468087 \\
\hline pemerintahan & 0.20 & 0.195863 \\
\hline Perdagangan & 0.20 & 0.189409 \\
\hline Jumlah penduduk & 0.13 & 0.148455 \\
\hline Peluang pekerjaan & 0.10 & 0.109573 \\
\hline
\end{tabular}

5. Memasukkan bobot entropy kesolusi optimal vikor dengan menggunakan persamaan:

$$
S_{i}=\sum_{i=1}^{n} w_{i}\left(f_{i}^{*}-f_{i j}\right) /\left(f_{i}^{*}-f_{i}^{-}\right)
$$

Dimana :

$\mathrm{S}_{\mathrm{i}}=$ Nilai solusi tertinggi

$\mathrm{R}_{\mathrm{i}}=$ Nilai solusi terendah

$\mathrm{w}_{\mathrm{i}}=$ Bobot dari setiap kriteria ditentukan menggunakan metode entropy.

Tabel 4 Solusi optimal

\begin{tabular}{|l|l|l|l|l|l|}
\hline \multirow{2}{*}{$\begin{array}{l}\text { Kriteria } \\
\text { Jarak (meter) }\end{array}$} & \multicolumn{5}{|c|}{ Lokasi } \\
\cline { 2 - 6 } & Alue lim & Blang buloh & Mane kareung & Asan kareung & Rayeuk kareng \\
\hline Pendidikan & 0.087234 & 0.115684 & 0.083347 & 0.094402 & 0.000000 \\
\hline Bank & 0.120390 & 0.069056 & 0.102721 & 0.000000 & 0.068729 \\
\hline Pusat kesehatan & 0.009238 & 0.000000 & 0.002582 & 0.032148 & 0.120626 \\
\hline pemerintahan & 0.000000 & 0.152955 & 0.186943 & 0.139710 & 0.195863 \\
\hline Perdagangan & 0.099004 & 0.000000 & 0.156360 & 0.144987 & 0.189409 \\
\hline Jumlah penduduk & 0.027698 & 0.017750 & 0.000000 & 0.148455 & 0.026356 \\
\hline Peluang pekerjaan & 0.057233 & 0.109573 & 0.033270 & 0.016910 & 0.000000 \\
\hline
\end{tabular}

6. Nilai maksimal dari solusi optimum.

$$
R_{i}=\max _{j}\left[w_{i}\left(f_{i}^{*}-f_{i j}\right) /\left(f_{i}^{*}-f_{i}^{-}\right)\right]
$$


Tabel 5 Solusi optimum

\begin{tabular}{|l|l|}
\hline Lokasi & Nilai \\
\hline Rayeuk kareung & 0.195863 \\
\hline MANE KAREUNG & 0.186943 \\
\hline ASAN KAREUNG & 0.148455 \\
\hline BLANG BULOH & 0.152955 \\
\hline ALUE LIM & 0.120390 \\
\hline
\end{tabular}

7. nilai perangkingan rasio

Setelah mendapatkan nilai solusi optimal dan solusi terendah. Nilai perangkingan dapat dihitung sebagai berikut:

$$
Q_{j}=v\left[\frac{S_{j}-S^{*}}{S^{-}-S^{*}}\right]+(1-v)\left[\frac{R_{j}-R^{*}}{R^{-}-R^{*}}\right]
$$

1

Tabel 6 Nilai rasio perangkingan

\begin{tabular}{|l|l|}
\hline Lokasi & Nilai \\
\hline RAYEUK KAREUNG & 1.000000 \\
\hline MANE KAREUNG & 0.851591 \\
\hline ASAN KAREUNG & 0.625052 \\
\hline BLANG BULOH & 0.376144 \\
\hline ALUE LIM & 0.000000 \\
\hline
\end{tabular}

7. Perhitungan copeland score untuk penggabungan penilaian para decision maker, sehingga diperoleh hasil akhir berupa urutan perangkingan lokasi. Perbandingan perhitungan berpasangan dengan semua masing-masing lokasi dibandingkan dan hasil yang didapat dari perbandingan di jadikan hasil pengurutan. Berikut penjelasan dari voting copeland score adalah:

1. Hasil Dari peringkat masing-masing decision maker yang akan dimasukkan kedalam perbandingan pairwise contest

Tabel 7 penilaian masing-masing Dinas

\begin{tabular}{|l|l|l|l|l|}
\hline No & Lokasi & DM1 & DM2 & DM3 \\
\hline 1 & ALUE LIM & 2 & 1 & 5 \\
\hline 2 & Blang Buloh & 1 & 4 & 4 \\
\hline 3 & Maneu Kareung & 5 & 3 & 2 \\
\hline 4 & Asan Kareung & 4 & 2 & 3 \\
\hline 5 & Rayeuk Kareung & 3 & 5 & 1 \\
\hline
\end{tabular}

2. Perbandingan pairwise contest dari masing-masing dinas untuk penentuan lokasi

3. Hasil dari pair wise contest

Tabel 8 peringkat voting

\begin{tabular}{|l|l|l|l|}
\hline No & Lokasi & Copeland score & Rangking \\
\hline 1 & alue lim & $0-8=-8$ & 5 \\
\hline 2 & Blang Buloh & $2-6=-4$ & 4 \\
\hline 3 & Maneu Kareung & $6-2=4$ & 2 \\
\hline 4 & Asan Kareung & $4-4=0$ & 3 \\
\hline 5 & Rayeuk Kareung & $8-0=8$ & 1 \\
\hline
\end{tabular}

\subsubsection{Rancangan basis data}

Rancangan basis data merupakan serangkaian pertanyaan spesifik yang relevan dengan berbagai pemrosesan data. Misalnya objek data yang akan diproses oleh sistem, komposisi masing-masing objek data, serta hubungan antara masing-masing objek data tersebut [4]. 
a. Entity Relationship Diagram (ERD)

Berdasarkan aturan bisnis yang ada, maka Entity Relationship Diagram (ERD), seperti yang ditunjukkan pada gambar 1.

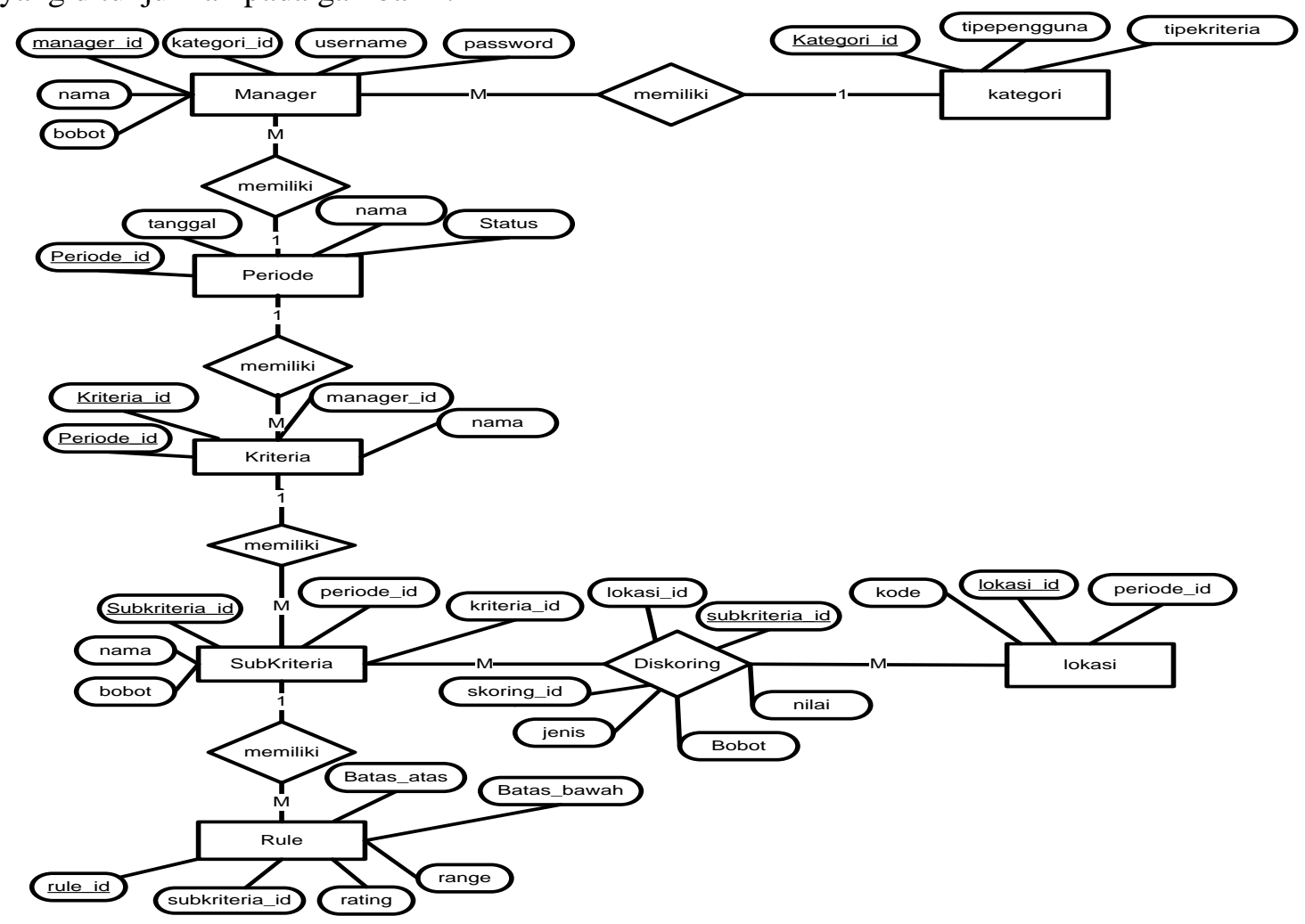

Gambar 1 ERD SPK kelompok penentuan lokasi kelayakan pemukiman

\subsubsection{Rancangan data flow diagram (DFD)}

Data Flow Diagram merupakan suatu gambaran grafis dari suatu sistem yang menggunakan bentuk-bentuk simbol untuk menggambarkan bagaimana data mengalir melalui suatu proses yang berkaitan.

Diagram konteks merupakan level tertinggi dari DFD yang menggambarkan seluruh input ke sistem atau output dari sistem. Diagram konteks sistem pendukung keputusan kelompok penentuan kelayakan lokasi pemukiman, dapat dilihat pada gambar 2.

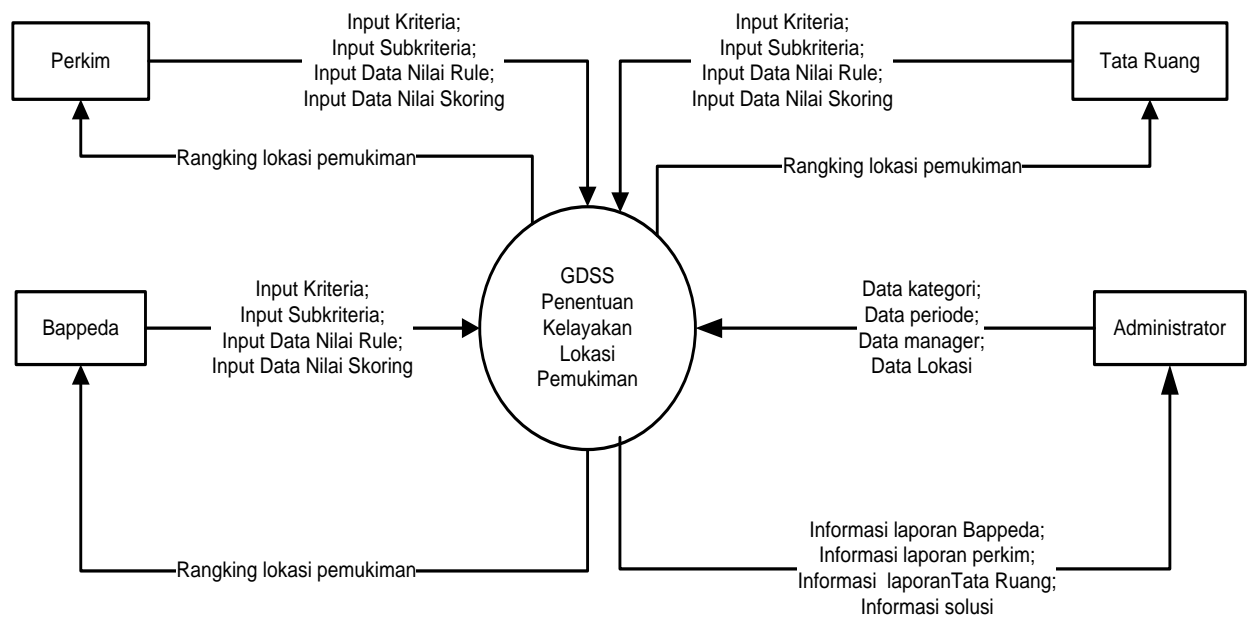

Gambar 2 Diagram konteks 
DFD level 0 terdiri dari Pada gambar 4.5 terdapat 4 buah entitas dan sebuah proses yaitu entitas decision maker bappeda, decision maker tata ruang, decision maker perkim, dan entitas administrator, dan proses GDSS penentuan kelayakan lokasi pemukiman. Dimana terdapat 2 aliran data yang masuk ke dalam proses dan 8 aliran data yang ke luar dari proses.

DFD level 1 terdapat 4 proses yaitu proses input data, proses penentuan lokasi, proses group, dan laporan. pengelolaan data periode. Proses yang berlangsung dapat dilihat pada gambar 3.

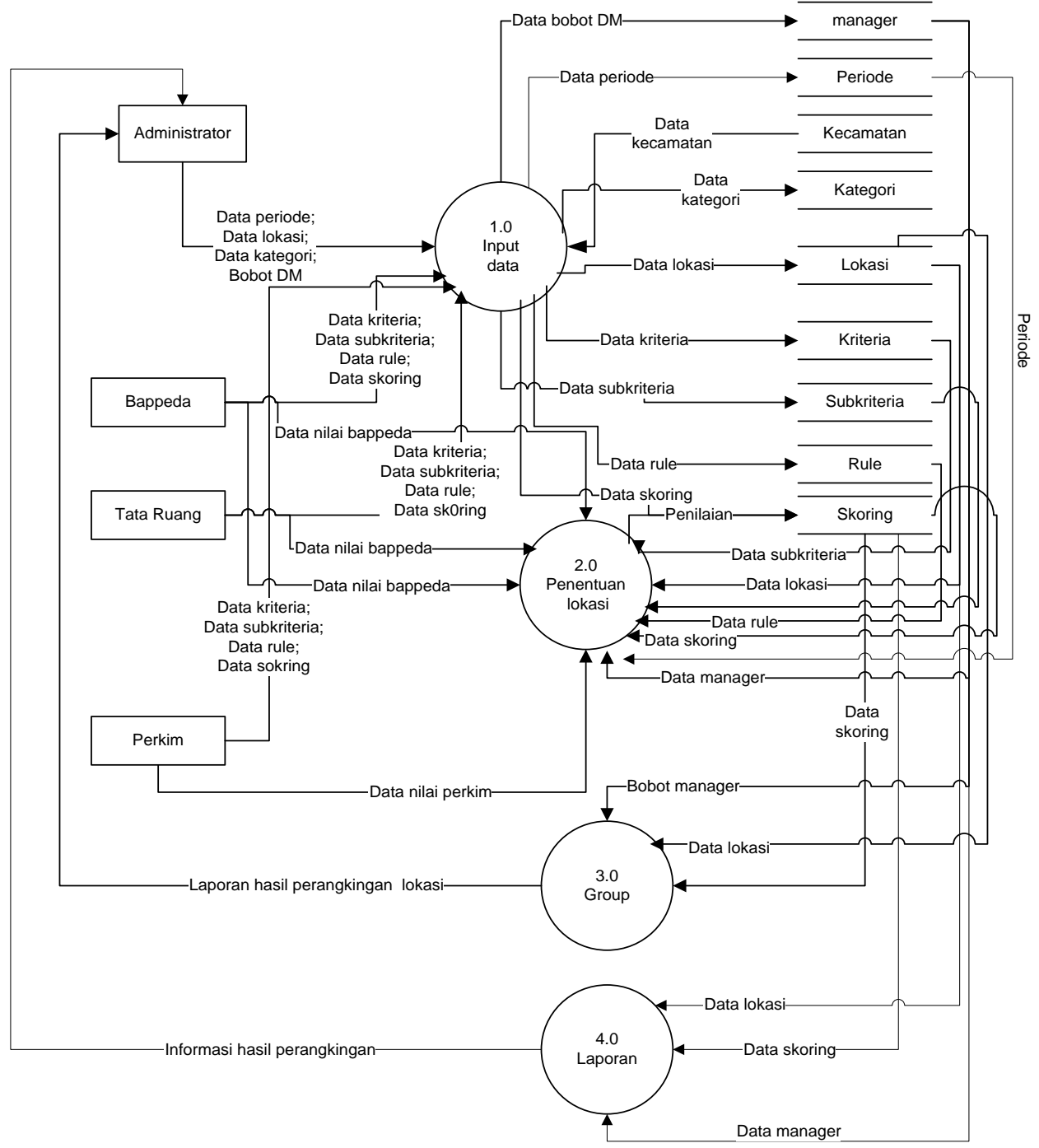

Gambar 3 DFD level 1

Pada gambar 4 DFD level 2 proses 2 pada DFD dipecah menjadi tiga buah proses. Pencocokan nilai entropy yang dimasukkan oleh decision maker pada tabel lokasi, tabel kriteria dan tabel subkriteria yang kemudian kedalam perhitungan entropy yang kemudian dimasukkan kedalam proses pencocokan nilai bobot rating. Data rating yang telah dimasukkan akan dilakukan proses normaliasi, data yang telah dinormalisasi akan masuk kepengukuran entropy, setelah mendapatkan hasil pengukuran entropy, diberikan bobot masing-masing untuk subkriteria sesuai dengan kepentingannya, terakhir melakukan perhitungan entropy dengan lamda untuk mengetahui hasil dari bobot yang digunakan. 


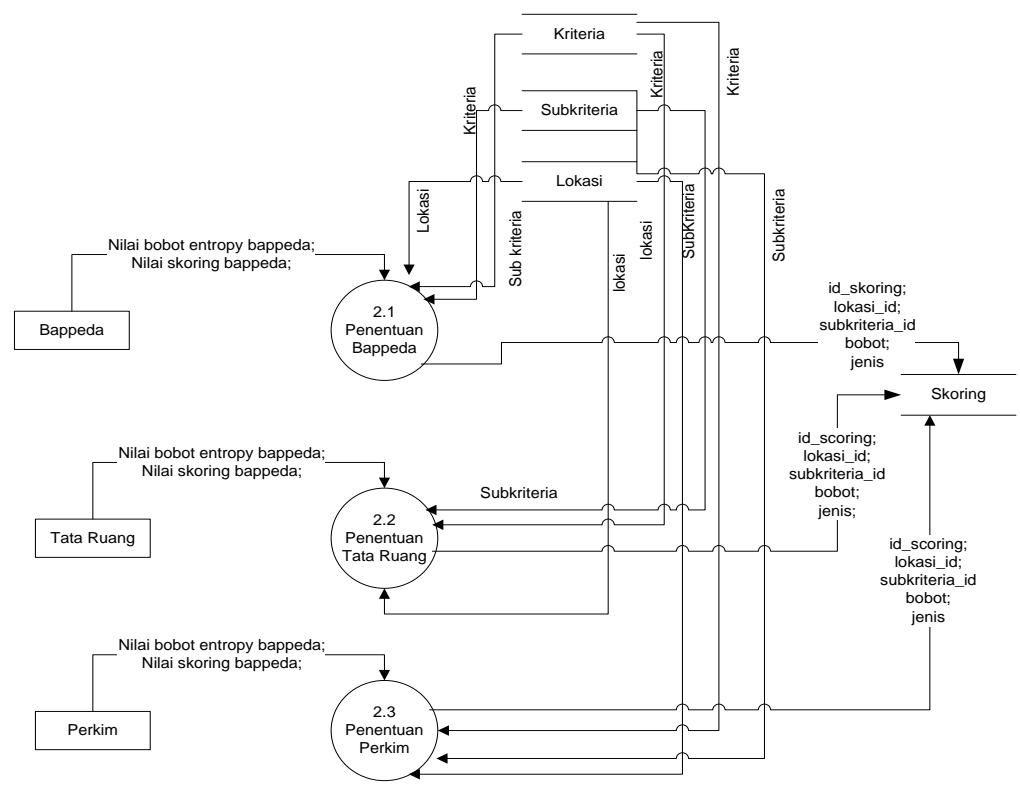

Gambar 4 DFD level 2 proses 2.0

\subsection{Implementasi}

Implementasi sistem pendukung keputusan kelompok penentuan dana korban konflik Aceh dibuat sesuai dengan arsitektur sistem pada rancangan sebelumnya.

\subsubsection{Lingkungan implementasi sistem}

Dalam pengimplementasian sistem ini dibutuhkan spesifikasi peralatan sebagai berikut :

a. Perangkat Keras (Hardware)

a. Intel $®$ Core i3 CPU $350 @ 2.26 \mathrm{GHz}$

b. Harddisk $500 \mathrm{~GB}$

b. Perangkat Lunak (Software)

a. Microsoft Windows XP

b. XAMPP for Windows 1.7.3

2.3.2 Implementasi sistem

Implementasi sistem sesuai dengan perancangan sebelumnya, antara lain yaitu :

a. Implementasi skoring

Pengelolaan data subkreteria merupakan implementasi dari DFD level 2 proses 11.0. Modul ini digunakan oleh decision maker untuk input, update, hapus, tampil data skoring. Berikut user interface dan potongan source code, dapat dilihat dapat dilihat pada gambar 5.

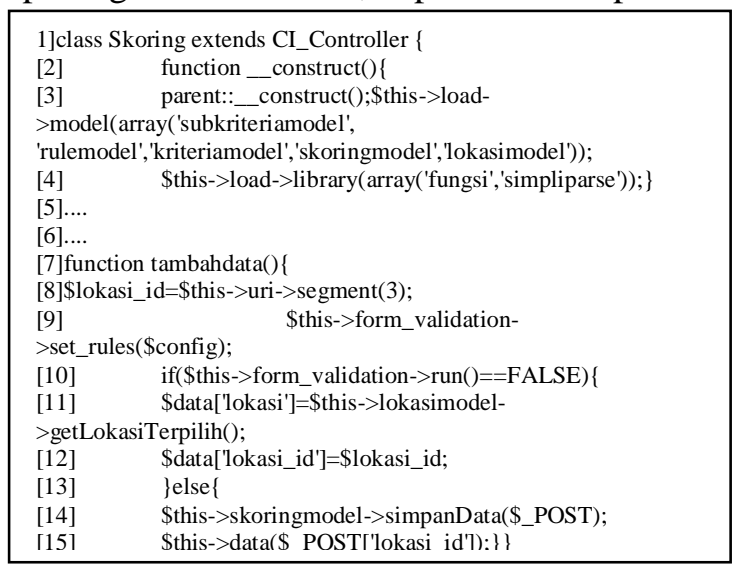

Gambar 5 User interface setup scoring 


\section{HASIL DAN PEMBAHASAN}

Beberapa test case dilakukan pada sistem untuk mengetahui kemampuan kinerja sistem, apakah sudah sesuai seperti yang diharapkan. Pengujian sampel data (test case) dilakukan terhadaplokasi atas masing-masing pengambil keputusan .

Test case yang dilakukan terdiri 2 tahap yaitu :

Pengujian tahap pertama dilakukan untuk dana bantuan pembangunan rumah, sampel data yang diuji berjumlah 6 lokasi pemukiman.

Pengujian tahap kedua untuk menguji penggabungan penilaian para decision maker menggunakan metode voting copelandscore. Skenario yang dilakukan pada pengujian ini adalah bila pengujian sistem dinas bappeda berhasil untuk dinas lainnya juga akan berhasil dilakukan. Hasil pengujian yang dilakukan dapat dilihat pada Gambar 8-9.

Pengujian pertama

\begin{tabular}{ccccc} 
No. & Lokasi & DM1 & DM2 & DM3 \\
1. & ALUE LIM & 4 & 6 & 1 \\
2. & ASAN KAREUNG & 1 & 3 & 4 \\
\hline 3. & BLANG BULOH & 6 & 5 & 3 \\
\hline 4. & COT GIREK & 2 & 4 & 2 \\
5. & MANE KAREUNG & 3 & 1 & 6 \\
6. & RAYEUK KAREUNG & 5 & 2 & 5
\end{tabular}

Gambar 6 Test case pertama

\begin{tabular}{lcc}
\multicolumn{1}{c}{ Lokasi } & Copeland Score & Rangking \\
\hline COT GIREK & $5-0=5$ & 1 \\
\hline ASAN KAREUNG & $4-1=3$ & 2 \\
\hline MANE KAREUNG & $3-2=1$ & 3 \\
\hline ALUE LIM & $2-3=-1$ & 4 \\
\hline RAYEUK KAREUNG & $1-4=-3$ & 5 \\
BLANG BULOH & $0-5=-5$ & 6 \\
\hline
\end{tabular}

Gambar 7 Test case pertama copeland score

\begin{tabular}{llccc} 
No. & Lokasi & DM1 & DM2 & DM3 \\
\hline 1 & ALUE LIM & $0.891087(1)$ & $0.091581(6)$ & $1.000000(1)$ \\
\hline 2 & ASAN KAREUNG & $0.497378(3)$ & $0.731235(3)$ & $0.237780(4)$ \\
\hline 3 & BLANG BULOH & $0.393862(5)$ & $0.409662(5)$ & $0.536775(3)$ \\
\hline 4 & COT GIREK & $0.435592(4)$ & $0.676411(4)$ & $0.991407(2)$ \\
\hline 5 & MANE KAREUNG & $0.200357(6)$ & $0.924043(1)$ & $0.098926(6)$ \\
\hline 6 & RAYEUK KAREUNG & $0.513380(2)$ & $0.770105(2)$ & $0.206073(5)$ \\
\hline
\end{tabular}

Gambar 8 Test case kedua

IJCCS Vol. 7, No. 1, January 2013: 89-100 


\begin{tabular}{lcc}
\multicolumn{1}{c}{ Lokasi } & Copeland Score & Rangking \\
\hline ALUE LIM & $5-0=5$ & 1 \\
\hline RAYEUK KAREUNG & $4-1=3$ & 2 \\
\hline COT GIREK & $3-2=1$ & 3 \\
\hline ASAN KAREUNG & $2-3=-1$ & 4 \\
\hline MANE KAREUNG & $1-4=-3$ & 5 \\
BLANG BULOH & $0-5=-5$ & 6 \\
\hline
\end{tabular}

Gambar 9 Test case kedua copeland score

Hasil dari proses perhitungan masing-masing decision maker, yaitu berupa nilai perangkingan alternatif lokasi pemukiman digunakan sebagai perhitungan bersama semua decision maker yang terlibat. Hasil dari pengujian kedua oleh Dinas PU tata ruang dan dinas PU pekim seperti pengujian pertama (Gambar 6) dan (Gambar 7) dikarenakan kriteria yang digunakan untuk pengujian kedua sama dengan pengujian pertama, rincian hasilnya sebagai berikut :

a. Lokasi Alue lim mempunyai nilai 0.091581 menduduki urutan ke-6

b. Asan Kareung mempunyai nilai 0.731235 menduduki urutan ke-3

c. Blang Buloh mempunyai nilai 0.409662 menduduki urutan ke-5

d. Cot Girek mempunyai nilai 0.676411 menduduki urutan ke-4

e. Mane Kareng mempunyai nilai 0.924043 menduduki urutan ke-1

f. Rayeuk Kareung mempunyai nilai menduduki urutan ke-2

Begitu pula untuk hasil dari pengujian kedua oleh dinas pu bidang perkim sama seperti pengujian pertama (Gambar 8 dan Gambar 9) dikarenakan kriteria yang digunakan untuk pengujian kedua sama dengan pengujian pertama, rincian hasilnya sebagai berikut:

a. Lokasi Alue lim mempunyai nilai 1,00000 menduduki urutan ke-1

b. Asan Kareung mempunyai nilai 0.237780 menduduki urutan ke-4

c. Blang Buloh mempunyai nilai 0.536775 menduduki urutan ke-3

d. Cot Girek mempunyai nilai 0.991407 menduduki urutan ke-2

e. Mane Kareng mempunyai nilai 0.098926 menduduki urutan ke-6

f. Rayeuk Kareung mempunyai nilai 0.206073 menduduki urutan ke-5

Perbedaan pada pengujian kedua terletak pada kriteria-kriteria yang dilakukan oleh dinas bappeda. Pada pengujian kedua, dinas bappeda mempunyai lokasi yang berbeda dengan pengujian yang pertama sehingga kriteria-kriterianya yang diperlukan berbeda

\section{KESIMPULAN}

Berdasarkan pembahasan yang telah diuraikan sebelumnya, maka diambil beberapa kesimpulan sebagai berikut :

1. Group decision Support System (GDSS) yang menggunakan metode VIKOR dan Copeland Score dapat digunakan dalam penentuan kelayakan lokasi pemukiman dikota Lhokseumawe.

2. Hasil yang diperoleh dari sistem adalah menampilkan nilai kalkulasi masing-masing alternatif yang dievaluasi dan menampilkan alternatif solusi yang diambil untuk menentukan lokasi yang layak akan direkomendasi menjadi suatu daerah pemukiman.

3. Untuk mengatasi perbedaan preferensi pada kelompok pengambil keputusan metode Copeland score dapat digunakan sebagai salah satu metode voting.

4. Data kriteria, tingkat kepentingan, dan rating pada sistem ini bersifat dinamis, dapat dirubah sesuai dengan kebutuhan pengambil keputusan. 


\section{SARAN}

1. Perlu dilakukan penelitian lebih lanjut dengan metode lain untuk perbandingan hasil atau mengkombinasikan dengan teknik AI dengan FMCDM.

2. Sistem hendaknya memiliki tampilan yang lebih menarik dan lebih mudah digunakan.

\section{DAFTAR PUSTAKA}

[1] Pressman, R.S., 2002, Rekayasa Perangkat Lunak, Buku satu, (diterjemahkan oleh: CN Harnaningrum), Andi, Yogyakarta.

[2] Athawale V.M.V., 2010, Selection of Industrial Robots using Compromise Ranking Method, Proceedings of the 2010 International Conference on Industrial Engineering and Operations Management, Bangladesh, January 9 - 10, 2010 Department of Production Engineering, Jadavpur University, India.

[3] Cristobal, J.R.S., Biezma, V.M., Martinez, R., and Somoza, R., 2009, Selection of materials under aggressive environments: the vikor method, International Conference on Integrity, Reliability and Failure, 20-24 July 2009, pp S1204_P0266. Nautical Science Department, 2 Materials Science and Technology Department University of Cantabria Santander, Spain.

[3] Jung, F.C., Ming, C.L., dan Jui, F.C., 2011, An Entropy Decision Model for Selection of Enterprise Resource Planning System, International Journal of Computer Trends and Technology- March to April Issue 2011, ISSN:2231-2803, pp1-9, National Kaohsiung University of Applied Science, Taiwan: http://www.ijcttjournal.org/volume-1/issue1/ijcttjournal-v1i1p30.pdf diakses 18 july 2011

[4] Silberschatz, A., Korth, H. F., dan Sudarshan, S., 2002, Database System Concepts, $4^{\text {th }}$ ed., McGraw-Hill. 